\title{
PENGARUH PENDEKATAN SAINTIFIK BERBASIS ASESMEN PROJEK TERHADAP HASIL BELAJAR MATEMATIKA
}

\author{
I M Dedy Setiawan \\ STMIK STIKOM Indonesia \\ dedy.setiawan86@yahoo.com
}

I N Arnawa

STMIK STIKOM Indonesia

nengaharnawa@gmail.com

\begin{abstract}
Abstrak
Salah satu cara mewujudkan tamatan yang berkualitas dimulai dengan mewujudkan proses pembelajaran yang berkualitas yaitu dengan mengimplementasikan pendekatan pembelajaran inovatif. Akan tetapi, selama ini pembelajaran matematika di kelas belum memberikan kesempatan kepada mahasiswa untuk mengembangkan kompetensinya, sementara dari segi penilaian pembelajaran masih bersifat konvensional hanya melalui tes di akhir pembelajaran, sehingga proses dalam pembelajaran kurang diperhatikan. Oleh karena itu, perlu diupayakan suatu inovasi dalam kegiatan pembelajaran. Salah satu alternatifnya adalah menerapkan pendekatan saintifik berbasis asesmen projek. Tujuan penelitian ini yaitu untuk mengetahui adanya pengaruh pendekatan saintifik berbasis asesmen projek terhadap hasil belajar matematika mahasiswa STMIK STIKOM Indonesia. Metode penelitian yang digunakan adalah quasi eksperimen dengan non equivalent control group design. Instrumen yang digunakan berupa tes hasil belajar matematika. Hasil penelitian menunjukkan bahwa terdapat pengaruh yang signifikan pendekatan saintifik berbasis asesmen projek terhadap hasil belajar matematika mahasiswa STMIK STIKOM Indonesia.
\end{abstract}

Kata Kunci: Asesmen Projek, Hasil Belajar, Pendekatan Saintifik

\begin{abstract}
One way to realize a quality graduate starts with realizing a quality learning process by implementing an innovative learning approach. However, so far learning mathematics in the classroom has not provided an opportunity for students to develop their competencies, while in terms of assessment learning is still conventional only through tests at the end of learning, so the process of learning is less heeded. Therefore, it is necessary to strive for innovation in learning activities. One alternative is to apply a scientific approach based on project assessment. The purpose of this study is to determine the influence of project-based scientific approach to project assessment of mathematics learning outcomes of STMIK STIKOM Indonesia students. The research method used was a quasi-experimental with non equivalent control group design. The instrument used in the form of mathematics learning achievement test. The results showed that there was a significant influence of the project assessment-based scientific approach to the mathematics learning outcomes of STMIK STIKOM Indonesia students.
\end{abstract}

Keywords: Project Assessment, Learning Outcomes, Scientific Approach

\section{Pendahuluan}

STMIK STIKOM Indonesia (STIKI) sebagai salah satu perguruan tinggi swasta yang mencetak sarjana profesional di bidang komputer tentunya tidak bisa lepas dari peran proses pembelajaran di kelas. Hasil belajar mahasiswa yang baik di setiap semester akan berdampak terhadap tamatan sarjana yang berkualitas. Harapannya tentu untuk menyiapkan sumber daya manusia dalam menghadapi tantangan dunia kerja di tengah pesatnya perkembangan teknologi.

Salah satu cara untuk mewujudkan tamatan yang berkualitas dimulai dengan mewujudkan proses pembelajaran yang berkualitas. Artinya dalam kegiatan pembelajaran, disamping peran mahasiswa dan dosen, juga diperlukan adanya implementasi teknik, metode, maupun pendekatan dalam pembelajaran yang sifatnya inovatif. Beberapa penelitian sudah membuktikan bahwa implementasi pembelajaran inovatif yang mengajak peserta didik aktif dalam kegiatan pembelajaran, mampu memberikan hasil belajar yang lebih baik dibandingkan pembelajaran konvensional yang cenderung bersifat teacher centered.

Berdasarkan observasi terhadap hasil belajar mahasiswa dalam dua semester terakhir dalam bentuk Ujian Tengah Semester (UTS) dan Ujian Akhir Semester (UAS) diperoleh rata-rata skor hasil belajar 
matematika mahasiswa masih perlu ditingkatkan, baik secara individu maupun klasikal. Berikut data skor ratarata hasil belajar matematika mahasiswa dalam dua semester terakhir.

Tabel 1. Rata-Rata Klasikal Skor Hasil Belajar Mahasiswa

\begin{tabular}{cccc}
\hline No. & Semester & UTS & UAS \\
\hline 1 & Ganjil & 70,50 & 68,50 \\
2 & Genap & 65,00 & 64,33 \\
\hline
\end{tabular}

Tabel 1 memperlihatkan bahwa rata-rata skor hasil belajar matematika mahasiswa dalam dua semester terakhir masih berada di bawah KKM yang ditetapkan yaitu 75, sehingga perlu adanya upaya perbaikan dalam proses pembelajaran di kelas. Ada beberapa faktor yang diidentifikasi sebagai penyebab rendahnya hasil belajar mahasiswa pada mata kuliah matematika diantaranya adalah pembelajaran yang masih didominasi dengan penggunaan metode ceramah. Dosen dalam hal ini berperan sebagai sumber informasi, sementara mahasiswa hanya duduk mendengarkan penjelasan dosen. Materi yang disampaikan terkesan monoton melalui slide presentasi dengan pemberian latihan soal di akhir pembelajaran. Selain itu penilaian dalam pembelajaran juga masih bersifat konvensional yang hanya dilakukan di akhir pembelajaran melalui tes. Model pembelajaran seperti ini tentunya tidak menanamkan pemahaman konsep kepada mahasiswa, sehingga ketika diberikan permasalahan yang memerlukan kemampuan berpikir tingkat tinggi atau permasalahan yang sifatnya tidak rutin, mahasiswa menjadi kebingungan dan berujung kepada nilai hasil ujian yang kurang memuaskan. Upaya yang telah dilakukan terkait usaha meningkatkan hasil belajar mahasiswa misalnya dengan menerapkan metode diskusi kelompok melalui presentasi, penugasan, sampai dengan metode scaffolding, namun belum memberikan hasil yang signifikan.

Melihat kondisi ini, perlu dicarikan solusi, salah satunya dengan mengimplementasikan pendekatan pembelajaran yang inovatif di kelas. Perkembangan dunia pendidikan menuntut dikembangkannya pendekatan pembelajaran. Hal ini seiring dengan perkembangan psikologis peserta didik, dinamika sosial, serta dinamika sistem pendidikan di setiap negara yang terus berubah. Salah satu pendekatan yang dapat digunakan dalam pembelajaran adalah pendekatan saintifik, yaitu pendekatan yang menggunakan langkah-langkah serta kaidah ilmiah dalam proses pembelajaran. Langkah ilmiah yang diterapkan meliputi menemukan masalah, merumuskan masalah, mengajukan hipotesis, mengumpulkan data, menganalisis data, dan menarik kesimpulan. Hal ini tentu saja memberikan kesempatan kepada mahasiswa untuk menunjukkan kompetensinya dalam pembelajaran sehingga pembelajaran menjadi lebih bermakna.

Menurut Rustam (2017) Penerapan pendekatan saintifik dalam setiap pembelajaran di setiap sekolah tentulah berbeda-beda dalam setiap aspeknya, hal ini terjadi karena tingkat pemahaman guru yang berbeda-beda pula dalam menerapkan pembelajaran yang berbasis saintifik. Di samping itu faktor kondisi dan kebutuhan sekolah yang berbeda-beda juga akan mempengaruhi. Menurut Hosnan (2014:34) mengemukakan pendekatan saintifik merupakan pembelajaran dirancang supaya peserta didik secara aktif mengkontruksi konsep, hukum atau prinsip melalui tahapan mengamati (untuk mengidentifikasi dan menemukan masalah), merumuskan masalah, mengajukan atau merumuskan hipotesis, mengumpulkan data dengan berbagai teknik, menganalisis data, menarik kesimpulan, mengkomunikasikan konsep serta hukum dan prinsip yang ditemukan. Menurut Hamidah (2015) Pendekatan saintifik merupakan proses mendekati penahaman pembelajaran secara ilmiah dengan menerapkan konsepkonsep penelitian ilmiah menuju pembelajaran yang bersifat empiris, aktif, kreatif dan efektif. Menurut Arifin (2018) Pendekatan saintifik memang bukanlah satu-satunya pendekatan dalam pembelajaran pada Kurikulum 2013, akan tetapi jika pendekatan saintifik diimplementasikan dalam pembelajaran akan melatih peserta didik secara aktif mengonstruk konsep, hukum atau prinsip melalui tahapantahapan mengamati (untuk mengidentifikasi atau menemukan masalah), merumuskan masalah, mengajukan atau merumuskan hipotesis, mengumpulkan data dengan berbagai teknik, menganalisis data, menarik kesimpulan dan mengomunikasikan konsep, hukum atau prinsip yang "ditemukan". Menurut Permatasari (2014) Pembelajaran dengan pendekatn saintifik adalah pembelajaran yng terdiri atas kegiatan mengamati (untuk mengidentifikasi masalah yang ingin diketahui), merumuskan pertanyaan dan merumuskan hipotesis, mengumpulkan data/informasi dengan berbagai teknik, mengolah/ menganalisis data/informasi dan menarik kesimpulan serta mengkomunikasikan hasil yang terdirii dari kesimpulan dan juga temuan lain di luar rumusan masalah untuk memperoleh pengetahuan, keterampilan dan sikap. Langkah-langkah tersebut dapat dilanjutkan dengan kegiatan mencipta. Beberapa penelitian sudah membuktikan bahwa pendekatan saintifik berkorelasi positif terhadap peningkatan hasil belajar mahasiswa. Misalnya penelitian tentang Pembelajaran Berbasis Saintifik terhadap Sikap Berpikir Ilmiah Mahasiswa Program Studi PGSD Universitas Negeri Manado. Selain itu, penelitian tentang pengaruh pendekatan saintifik terhadap hasil belajar menunjukkan adanya pengaruh yang signifikan.

Penilaian dalam pembelajaran juga penting dilakukan disamping penerapan pendekatan dalam pembelajaran. Penilaian dalam hal ini disebut asesmen dilakukan selama proses kegiatan pembelajaran berlangsung untuk mengetahui sejauhmana kemampuan mahasiswa dalam menunjukkan kompetensinya 
sehingga bisa digunakan sebagai bahan atau informasi mengambil keputusan terkait proses pembelajaran berikutnya. Asesmen Projek merupakan salah satu jenis asesmen yang bisa diterapkan dalam proses pembelajaran. Karakteristik dari asesmen ini adalah adanya tahapan-tahapan yang sistematis mulai dari fase perencanaan, fase pengembangan, dan fase akhir, sehingga dalam asesmen projek, guru tidak hanya melakukan evaluasi akhir yang hanya mengukur tingkat kemampuan yang rendah saja melalui tes tertulis (paper and pencil test) melainkan penilaian kemampuan pemecahan masalah lebih ditekankan pada proses. Hal ini tentunya relevan dengan pendekatan saintifik dalam pembelajaran yang sama-sama mengedepankan penilaian proses dalam pembelajaran melalui tahapan-tahapan ilmiah, sehingga melalui pendekatan saintifik berbasis asesmen projek dalam pembelajaran diharapkan mampu meningkatkan hasil belajar mahasiswa STMIK STIKOM Indonesia pada mata kuliah matematika. Tujuan dari penelitian ini adalah untuk mengetahui pengaruh pendekatan saintifik berbasis asesmen projek terhadap hasil belajar matematika mahasiswa STMIK STIKOM Indonesia.

\section{Metode}

Populasi dalam penelitian ini adalah mahasiswa STIKI semester ganjil tahun ajaran 2019/2020. Sampel diambil sebanyak dua kelas pada Program Studi Teknik Informatika. Pengambilan sampel dilakukan secara random. Penelitian dilaksanakan di STIKI pada program studi teknik informatika semester ganjil 2019/2020 yang didesain selama 10 kali pertemuan yaitu Bulan September - Oktober 2019.

Penelitian ini merupakan quasi eksperimen dengan non equivalent control group desaign, karena tidak merubah kelas yang sudah ada. Variabel dalam penelitian ini yaitu pendekatan saintifik berbasis asesmen projek sebagai variabel bebas dan hasil belajar matematika sebagai variabel terikat

Tahapan penelitian terbagi menjadi tahap persiapan, tahap pelaksanaan, dan tahap akhir yang masingmasing dijelaskan sebagai berikut. Langkah-langkah yang dilakukan dalam tahap persiapan, antara lain: (1) Melakukan prariset untuk memperoleh informasi seputar penelitian yang akan dilakukan; (2) Analisis perangkat pembelajaran berupa RPS; (3) Membuat instrumen penelitian berupa tes hasil belajar ; (4) melakukan validasi instrumen; (5) Melakukan revisi instrumen yang dilakukan; (6) Melakukan uji coba soal; (7) Menganalisis data hasil uji coba. Pelaksanaan penelitian meliputi: (1) Menentukan jadwal penelitian; (2) Memberikan soal pretest sebelum melakukan perlakuan; (3) Melakukan pembelajaran dengan menggunakan pendekatan saintifik berbasis asesmen projek pada kelas eksperimen; (4) Melakukan pembelajaran dengan menggunakan metode ceramah pada kelas kontrol; (5) Memberikan soal posttest setelah diberikan perlakuan; (6) Memberikan tes hasil belajar setelah diberikan treatmen. Tahap akhir dari penelitian ini adalah: (1) Mengelola data yang telah diperoleh dari hasil pretest dan posttest serta penyebaran angket dengan uji statistik; (2) Mendeskripsikan hasil analisis data dan memberikan kesimpulan sebagai jawaban dari rumusan masalah; (3) Menyusun laporan penelitian.

Instrumen yang digunakan dalam penelitian ini adalah tes hasil belajar matematika. Sebelum data dikumpulkan terlebih dahulu instrumen diperiksa oleh expert judges, selanjutnya dilakukan pengujian empirik untuk menguji validitas dan reliabilitas butir instrumen masing-masing variabel. Analisis data dalam penelitian ini meliputi analisis deskriptif, uji prasyarat analisis, dan uji hipotesis. Analisis deskriptif dilakukan untuk mengetahui ukuran pemusatan dan sebaran data. Uji prasyarat analisis terdiri dari uji normalitas menggunakan uji Kolmogorov-smirnov dan uji homogenitas varian dengan uji levene. Uji hipotesis menggunakan anava satu jalur dengan membandingkan rata-rata skor hasil belajar antar kelompok, dengan ketentuan tolak Ho jika signifikansi kurang dari 5\%. Uji lanjut dilakukan apabila perbedaan yang diperoleh ternyata signifikan.

\section{Hasil dan Pembahasan}

Objek dalam penelitian ini adalah perbedaan hasil belajar matematika mahasiswa STMIK STIKOM Indonesia sebagai hasil perlakuan (treatment) pendekatan saintifik berbasis asesmen projek. Oleh karena itu, variabel penelitian dibedakan menjadi variabel bebas yaitu pendekatan saintifik berbasis asesmen projek dan variabel terikatnya hasil belajar matematika. Terdapat empat kelompok data dalam penelitian ini yaitu kelompok eksperimen dan kelompok kontrol yang masing-masing terbagi menjadi dua kelompok yaitu kelompok sebelum dan sesudah diberikan perlakuan. Setelah adanya perlakuan, diperoleh hasil penelitian yang meliputi data hasil penelitian secara deskriptif, data hasil uji prasyarat analisis, dan data hasil uji hipotesis. Berikut analisis data hasil belajar matematika secara deskriptif kelas eksperimen dan kelas kontrol sebelum dan sesudah diberikan perlakuan. 
Tabel 2. Deskripsi Data Hasil Belajar Matematika

\begin{tabular}{|c|c|c|c|c|c|}
\hline & & Pretest eksp & Posttest eksp & Pretest kontrol & Posttest kontrol \\
\hline $\mathbf{N}$ & Valid & 30 & 30 & 30 & 30 \\
\hline Mean & & 68.63 & 76.03 & 67.36 & 69.3 \\
\hline Median & & 68 & 76 & 68 & 70 \\
\hline Mode & & 60 & 80 & 60 & 70 \\
\hline Std. Deviation & & 8.97 & 6.94 & 9.32 & 8.69 \\
\hline Variance & & 80.51 & 48.24 & 86.93 & 75.52 \\
\hline Minimum & & 50 & 60 & 50 & 50 \\
\hline Maximum & & 85 & 90 & 85 & 80 \\
\hline
\end{tabular}

Data hasil belajar matematika yang mengikuti pembelajaran dengan pendekatan saintifik berbasis asesmen projek sebelum diberikan perlakuan (pretest) mempunyai rentangan skor teoretik $0-100 ; \mathrm{n}=30$; skor maksimum $=85$; skor minimum 50; jangkauan $=35$; banyak kelas interval $=6$; panjang kelas interval $=6$; ratarata $=68,63$; simpangan baku $(\mathrm{SD})=8,97$; modus $=60 ;$ dan median $=68$. Distribusi frekuensi data seperti pada Tabel 3 berikut.

Tabel 3. Distribusi Frekuensi Kelas Eksperimen (Pretest)

\begin{tabular}{ccccc}
\hline No. & Interval Kelas & Nilai Tengah & Frekuensi Absolut & $\begin{array}{c}\text { Frekuensi Relatif } \\
(\boldsymbol{\%})\end{array}$ \\
\hline 1 & $50-55$ & 52,5 & 3 & 10 \\
2 & $56-61$ & 58,5 & 5 & 16,67 \\
3 & $62-67$ & 64,5 & 6 & 20 \\
4 & $68-73$ & 70,5 & 5 & 16,67 \\
5 & $74-79$ & 76,5 & 7 & 23,33 \\
6 & $80-85$ & 82,5 & 4 & 13,33 \\
\hline & Jumlah & & $\mathbf{3 0}$ & $\mathbf{1 0 0}$ \\
\hline
\end{tabular}

Tabel 3 memperlihatkan bahwa sebanyak 16,67\% siswa memperoleh skor hasil belajar matematika sekitar rata-rata, 36,66\% siswa memperoleh skor di atas rata-rata, dan 46,67\% siswa memperoleh skor di bawah rata-rata.

Data hasil belajar matematika yang mengikuti pembelajaran dengan pendekatan saintifik berbasis asesmen projek setelah diberikan perlakuan (posttest) mempunyai rentangan skor teoretik $0-100 ; \mathrm{n}=30$; skor maksimum $=90$; skor minimum 60; jangkauan $=30$; banyak kelas interval $=6$; panjang kelas interval $=6$; ratarata $=76,03$; simpangan baku $(\mathrm{SD})=6,94$; modus $=80 ;$ dan median $=76$. Distribusi frekuensi data seperti pada Tabel 4 berikut.

Tabel 4 memperlihatkan bahwa sebanyak 23,33\% siswa memperoleh skor hasil belajar matematika sekitar rata-rata, 46,67\% siswa memperoleh skor di atas rata-rata, dan 30\% siswa memperoleh skor di bawah rata-rata.

Tabel 4. Distribusi Frekuensi Kelas Eksperimen (Posttest)

\begin{tabular}{ccccc}
\hline No. & Interval Kelas & Nilai Tengah & Frekuensi Absolut & $\begin{array}{c}\text { Frekuensi Relatif } \\
(\boldsymbol{\%})\end{array}$ \\
\hline 1 & $60-65$ & 62,5 & 3 & 10 \\
2 & $66-71$ & 68,5 & 6 & 20 \\
3 & $72-77$ & 74,5 & 7 & 23,33 \\
4 & $78-83$ & 80,5 & 10 & 33,33 \\
5 & $84-89$ & 86,5 & 2 & 6,67 \\
6 & $90-95$ & 92,5 & 2 & 6,67 \\
\hline
\end{tabular}


Data hasil belajar matematika yang mengikuti pembelajaran dengan pendekatan konvensional sebelum diberikan perlakuan (pretest) mempunyai rentangan skor teoretik $0-100 ; \mathrm{n}=30$; skor maksimum $=85$; skor minimum 50; jangkauan $=35$; banyak kelas interval $=6$; panjang kelas interval $=6$; rata-rata $=67,36$; simpangan baku $(\mathrm{SD})=9,32 ;$ modus $=60 ;$ dan median $=68$. Distribusi frekuensi data seperti pada Tabel 5 berikut.

Tabel 5. Distribusi Frekuensi Kelas Kontrol (Pretest)

\begin{tabular}{ccccc}
\hline No. & Interval Kelas & Nilai Tengah & Frekuensi Absolut & $\begin{array}{c}\text { Frekuensi Relatif } \\
(\boldsymbol{\%})\end{array}$ \\
\hline 1 & $50-55$ & 52,5 & 5 & 16,67 \\
2 & $56-61$ & 58,5 & 6 & 20 \\
3 & $62-67$ & 64,5 & 4 & 13,33 \\
4 & $68-73$ & 70,5 & 5 & 16,67 \\
5 & $74-79$ & 76,5 & 6 & 20 \\
6 & $80-85$ & 82,5 & 4 & 13,33 \\
\hline \multicolumn{7}{r}{} & & $\mathbf{3 0}$ & $\mathbf{1 0 0}$ \\
\hline
\end{tabular}

Tabel 5 memperlihatkan bahwa sebanyak 16,67\% siswa memperoleh skor hasil belajar matematika sekitar rata-rata, 33,33\% siswa memperoleh skor di atas rata-rata, dan 50\% siswa memperoleh skor di bawah rata-rata.

Data hasil belajar matematika yang mengikuti pembelajaran dengan pendekatan konvensional sebelum diberikan perlakuan (posttest) mempunyai rentangan skor teoretik $0-100 ; \mathrm{n}=30$; skor maksimum $=80$; skor minimum 50; jangkauan $=30$; banyak kelas interval $=6$; panjang kelas interval $=6$; rata-rata $=69,3$; simpangan baku $(\mathrm{SD})=8,69$; modus $=70$; dan median $=70$. Distribusi frekuensi data seperti pada Tabel 6 berikut.

Tabel 6. Distribusi Frekuensi Kelas Kontrol (Posttest)

\begin{tabular}{ccccc}
\hline No. & Interval Kelas & Nilai Tengah & Frekuensi Absolut & $\begin{array}{c}\text { Frekuensi Relatif } \\
(\boldsymbol{\%})\end{array}$ \\
\hline 1 & $50-55$ & 52,5 & 2 & 6,67 \\
2 & $56-61$ & 58,5 & 8 & 26,67 \\
3 & $62-67$ & 64,5 & 2 & 6,67 \\
4 & $68-73$ & 70,5 & 6 & 20 \\
5 & $74-79$ & 76,5 & 6 & 20 \\
6 & $80-85$ & 82,5 & 6 & 20 \\
\hline & Jumlah & $\mathbf{3 0}$ & $\mathbf{1 0 0}$ \\
\hline
\end{tabular}

Tabel 6 memperlihatkan bahwa sebanyak 20\% siswa memperoleh skor hasil belajar matematika sekitar rata-rata, 40\% siswa memperoleh skor di atas rata-rata, dan $40 \%$ siswa memperoleh skor di bawah rata-rata.

Hasil Uji Prasyarat dari empat kelompok data meliputi uji normalitas sebaran data dan uji homogenitas varian. Uji normalitas menggunakan uji Kolmogorov-Smirnov, sedangkan uji homogenitas varian menggunakan Levene test dengan taraf signifikansi 5\%. Hasil uji prasyarat sesuai Tabel 7 dan Tabel 8 yang disajikan berikut.

Tabel 7. Hasil Uji Homogenitas Varian

\begin{tabular}{|c|c|c|c|}
\hline \multicolumn{4}{|c|}{ Test of Homogeneity of Variances } \\
\hline \multicolumn{4}{|c|}{ Hasil Belajar Matematika } \\
\hline Levene Statistic & df1 & df2 & Sig. \\
\hline 1.967 & 1 & 58 & .166 \\
\hline
\end{tabular}

Berdasarkan Tabel 7 diperoleh nilai signifikansi 0,166>0,05 sehingga $\mathrm{H}_{0}$ diterima dan $\mathrm{H}_{1}$ ditolak yang berarti sebaran data homogen. 
Tabel 8. Hasil Uji Normalitas Data

\begin{tabular}{lcccccc}
\hline \multicolumn{1}{c}{ Kolmogorov-Smirnov } & \multicolumn{3}{c}{ Shapiro-Wilk } \\
\hline \multicolumn{1}{c}{ kelompok } & Statistic & df & Sig. & Statistic & df & Sig. \\
\hline eks_pratest & .128 & 30 & $.200^{*}$ & .970 & 30 & .542 \\
eks_posttest & .151 & 30 & .080 & .960 & 30 & .311 \\
kon_pratest & .152 & 30 & .075 & .955 & 30 & .232 \\
kon_posttest & .144 & 30 & .114 & .917 & 30 & .022 \\
\hline
\end{tabular}

Berdasarkan Tabel 8 diperoleh nilai signifikansi lebih dari 5\% sehingga $\mathrm{H}_{0}$ diterima dan $\mathrm{H}_{1}$ ditolak yang berarti data berdistribusi normal.

Uji Hipotesis menggunakan One-Way Anova dengan taraf signifikansi 5\%. Berikut Hasil uji hipotesis. Berdasarkan Tabel 9 diperoleh nilai $\mathrm{F}=10,989$ dan signifikansi $0,002<5 \%$ sehingga $\mathrm{H}_{0}$ ditolak dan $\mathrm{H}_{1}$ diterima, yang berarti perbedaan antar kelompok signifikan. Dilanjutkan dengan uji lanjut menggunakan uji LSD. Berdasarkan hasil uji lanjut, dapat dijelaskan bahwa hasil belajar kelompok eksperimen setelah mendapatkan perlakuan (kelompok 2 pada tabel) memiliki perbedaan rata-rata hasil belajar yang signifikan dibandingkan kelompok yang lain dengan nilai signifikansi masing-masing kurang dari 5\%.

Tabel 9. Hasil Uji Hipotesis

\begin{tabular}{lccccc}
\hline & Sum of Squares & df & Mean Square & F & Sig. \\
\hline Between Groups & 680.067 & 1 & 680.067 & 10.989 & .002 \\
Within Groups & 3589.267 & 58 & 61.884 & & \\
\hline \multicolumn{1}{c}{ Total } & $\mathbf{4 2 6 9 . 3 3 3}$ & $\mathbf{5 9}$ & & & \\
\hline
\end{tabular}

Penelitian ini melibatkan dua kelompok sampel yaitu kelompok eksperimen dengan perlakuan (treatmen) berupa pendekatan saintifik berbasis asesmen projek dan kelompok kontrol melalui pendekatan konvensional. Sebelum perlakuan diberikan, masing-masing kelompok mengikuti tes awal berupa pretest mata kuliah matematika I untuk mengetahui kemampuan awal mahasiswa STMIK STIKOM Indonesia. Hasil tes awal ini selain bisa dipakai untuk menentukan keseteraan kelas, juga bisa digunakan sebagai pembanding hasil belajar matematika sebelum dan sesudah mengikuti pembelajaran di kelas. Hal ini dilakukan untuk meminimalisir adanya pengaruh variabel lain yang tidak diteliti sehingga perbedaan hasil belajar matematika memang disebabkan oleh perlakuan yang diberikan. Perbedaan hasil belajar yang diperoleh selanjutnya dianalisis secara statistik menggunakan uji anava satu jalur (Anova one-way). Hasil uji Anava menunjukkan adanya perbedaan yang signifikan antara empat kelompok data dengan nilai $\mathrm{F}$ hitung sebesar 10,989 dan signifikansi kurang dari $5 \%$ yaitu kelompok eksperimen dan kontrol, sebelum dan setelah perlakuan.

Berdasarkan hasil tes awal diperoleh rata-rata skor hasil belajar matematika kelompok eksperimen sebesar 68,63 yang tidak berbeda secara signifikan berdasarkan uji statistik, dengan rata-rata skor hasil belajar matematika kelompok kontrol yaitu sebesar 67,36. Hal ini dapat dijelaskan bahwa kemampuan awal masingmasing kelompok adalah setara, sehingga layak untuk digunakan sebagai subjek penelitian dengan perlakuan yang sudah dirancang sesuai dengan perencanaan penelitian. Setelah mengikuti pembelajaran dalam jangka waktu yang sudah ditentukan yaitu 10 kali pertemuan ( 9 kali tatap muka dan 1 kali tes hasil belajar) maka diperoleh rata-rata skor hasil belajar matematika kedua kelompok memiliki perbedaan yang signifikan secara statistik (uji lanjut LSD). Rata-rata skor hasil belajar matematika kelompok mahasiswa yang mengikuti pembelajaran dengan pendekatan saintifik berbasis asesmen projek sebesar 76,03 lebih tinggi dari rata-rata skor hasil belajar kelompok mahasiswa yang mengikuti pembelajaran dengan pendekatan konvensional yaitu sebesar 69,30. Hal ini juga menunjukkan rata-rata skor hasil belajar matematika sebelum dan sesudah perlakuan memiliki perbedaan yang signifikan pada kelompok mahasiswa yang mengikuti pembelajaran dengan pendekatan saintifik berbasis asesmen projek.

Pembelajaran dengan pendekatan saintifik sangat relevan dengan penerapan asesmen projek. Kesesuaiannya terletak pada tahapan projek yang harus dilalui peserta didik bersama tenaga pendidik, yang di dalamnya sesuai dengan langkah dan kaidah ilmiah. Misalnya pada mata kuliah matematika I di STMIK STIKOM Indonesia tentang materi fungsi, implementasi pendekatan saintifik dimulai dari tahapan mengamati. Pada tahap ini, mahasiswa diberikan projek berupa cara menentukan karakteristik fungsi linier, fungsi kuadratik, fungsi eksponensial, dan fungsi logaritma, mulai dari mengidentifikasi unsur-unsur fungsi seperti pengertian fungsi, pengertian variabel, konstanta, suku, dan koefisien, menentukan nilai fungsi, sampai dengan menggambarkan fungsi tersebut pada Koordinat Kartesius. Mahasiswa diarahkan untuk berdiskusi dan terlibat 
langsung dalam mengamati projek yang diberikan dalam kelompok belajar yang beranggotakan 5 orang. Kompetensi yang ingin dikembangkan melalui pengalaman belajar mengamati adalah melatih kesungguhan, ketelitian, dan kemampuan mencari informasi.

Pada tahap menanya, mahasiswa difasilitasi untuk membuat pertanyaan mengenai apa yang belum dipahami terkait materi fungsi, pengertian fungsi, grafik fungsi, dan penerapannya pada masalah nyata. Mahasiswa pun terlihat serius dan antusias berduskusi dengan teman kelompoknya. Kompetensi yang dikembangkan pada tahap menanya adalah pengembangan kreativitas, rasa ingin tahu, kemampuan merumuskan pertanyaan untuk pengembangan keterampilan berpikir kritis, dan pembentukan karakter pebelajar sepanjang hayat. Terjadinya kegiatan menanya oleh peserta didik dapat disebabkan belum dipahaminya hal-hal yang diamati, atau dapat pula karena ingin mendapatkan informasi tambahan tentang hal-hal yang diamati [5]. Adanya asesmen projek pada tahapan menanya dapat membantu mahasiswa untuk membuat pertanyaan sendiri tanpa dibantu oleh peneliti, sehingga pembelajaran menjadi lebih bermakna.

Pada tahap mengumpulkan informasi, mahasiswa difasilitasi untuk mencari sumber informasi terkait pengertian fungsi, karakteristik, cara menggambar grafik fungsi, sampai dengan aplikasi fungsi dalam kehidupan nyata. sumber informasi bisa berupa buku, jurnal, narasumber, ataupun informasi melalui internet. Sumber informasi ini ditulis dengan jelas, lengkap dengan uraian dan waktu pencariannya. Adapun kompetensi yang ingin diwujudkan pada tahap ini adalah mahasiswa mampu mengembangkan sikap teliti, jujur, sopan, menghargai pendapat orang lain, memiliki kemampuan berkomunikasi, memiliki kemampuan mengumpulkan informasi dengan beragam cara, mengembangkan kebiasaan belajar, hingga menjadi seorang pebelajar sepanjang hayat.

Pada tahap menalar, mahasiswa difasilitasi untuk menganalisis dan membuat kategori dari unsur-unsur yang terdapat pada pengertian fungsi, grafik fungsi, dan penerapannya pada masalah nyata. Menghubungkan unsur-unsur yang sudah dikategorikan sehingga dapat dibuat kesimpulan mengenai pengertian fungsi, grafik fungsi, dan penerapannya pada masalah nyata. Asesmen projek tetap dilakukan dengan mengamati hasil pekerjaan mahasiswa dan disesuaikan dengan format penyekoran asesmen projek yang telah disusun. Melalui tahapan belajar ini diharapkan mahasiswa akan mengembangkan sikap jujur, teliti, disiplin, taat kepada aturan, bekerja keras, mampu menerapkan suatu prosedur dalam berpikir secara deduktif atau induktif untuk menarik suatu kesimpulan.

Tahap selanjutnya yaitu mengkomunikasikan. Pada tahap ini mahasiswa difasilitasi untuk saling berdiskusi antar kelompok, mempresentasikan hasil projeknya untuk ditanggapi oleh kelompok lain. Misalnya kelompok 1 menyampaikan pengertian fungsi disertai dengan beberapa contoh, kelompok 2 menyampaikan pengertian nilai fungsi dan karakteristiknya, kelompok 3 menggambar fungsi linier dan kuadratik lengkap dengan lengkah-langkahnya, dan seterusnya. Pada saat menggambar fungsi, mahasiswa mampu menggunakan beberapa aplikasi seperti flash player. Pada tahap ini mahasiswa menunjukkan kompetensinya dalam hal pengembangan sikap jujur, teliti, toleransi, berpikir secara sistematis, mengutarakan pendapat dengan cara yang singkat dan jelas, hingga berkemampuan berbahasa secara baik dan benar melalui pembelajaran yang kolaboratif, interaktif, dan menyenangkan.

Pada prinsipnya konsep dalam matematika menjadi mudah diimplementasikan untuk memecahkan masalah khususnya matematika ketika mahasiswa terlibat langsung dalam menemukan konsep tersebut melalui pendekatan pembelajaran yang sifatnya kolaboratif. Kegiatan pembelajaran seperti ini ternyata mampu diakomodasi oleh pendekatan saintifik dalam pembelajaran matematika, dibandingkan hanya mengandalkan transfer informasi yang bersifat satu arah seperti pada pembelajaran konvensional. Pendekatan saintifik merupakan suatu proses pembelajaran yang dirancang sedemikian rupa agar peserta didik secara aktif mengkonstruksi konsep matematika, melalui kegiatan mengamati, menanya, mengumpulkan informasi, menalar, dan mengkomunikasikan.

Sebagai pendekatan pembelajaran inovatif yang sesuai dengan karakteristik kurikulum saat ini, pendekatan saintifik menjadi pilihan dalam pembelajaran di kelas. Selain mampu melatih peserta didik untuk mengkonstruksi sendiri aspek kognitifnya, pendekatan saintifik juga mampu melatih peserta didik untuk menumbuhkan karakter positif melalui kegiatan kolaboratif, pembentukan kelompok, dan diskusi dengan peserta didik lainnya. Hal ini tentunya sangat membantu melatih peserta didik agar selalu berpikir kritis, sistematis, dan divergen dalam menghadapi persoalan khususnya yang berhubungan dengan matematika, mampu menalar dan berkomunikasi, serta memecahkan masalah. Implikasinya tentu pada meningkatnya hasil belajar matematika peserta didik itu sendiri, disamping dampak penting lainnya yaitu terbentuknya karakter positif melalui kepribadian yang cerdas secara intelektual maupun sosial. Implementasi ini sejalan dengan penelitian yang berjudul meningkatkan aktivitas dan hasil belajar mata kuliah pengetahuan lingkungan hidup melalui pendekatan scientific mahasiswa. Hasil penelitian menunjukan terjadi peningkatan hasil belajar sebesar 12,40\% selama dua siklus berdasarkan pendekatan saintifik yang diterapkan dalam pembelajaran. Penelitian lain tentang efektivitas penggunaan pendekatan saintifik dalam pemebalajran dengan judul The Effect of Using the Scientific Approach Through Concept Understanding and Critical Thinking in Science. Hasil penelitian menunjukkan bahwa pendekatan saintifik efektif dalam meningkatkan pemahaman konsep dan kemampuan berpikir kritis. 
Hasil penelitian ini memberikan implikasi bahwa pendekatan dalam pembelajaran yang sifatnya inovatif serta mengedepankan cara berpikir ilmiah, sangat penting untuk diimplementasikan dalam pembelajaran di kelas. Begitu juga penilaian dalam pembelajaran dalam hal ini berbentuk asesmen juga sangat penting diterapkan, karena tidak cukup penilaian dalam pembelajaran hanya dilakukan di akhir saja melalui tes tertulis. Penilaian atau asesmen hendaknya dilakukan disetiap proses kegiatan pembelajaran, sehingga apa yang menjadi kendala peserta didik mampu kita evaluasi dan carikan solusinya. Hal ini tiada lain untuk meningkatkan hasil belajar sehingga tujuan pembelajaran bisa tercapai. Melalui pendekatan saintifik berbasis asesmen projek, mampu memfasilitasi kegiatan pembelajaran melalui langkah-langkah metode ilmiah sekaligus menilai proses pembelajaran secara keseluruhan melalui penugasan projek yang juga sifatnya ilmiah, sistematis, dan mampu melatih kemampuan siswa berpikir kritis. Asesmen projek yang sifatnya otentik sangat relevan untuk digunakan di kelas karena memungkinkan peserta didik untuk melakukan aktivitas belajar saintifik berupa kegiatan bertanya, melakukan pengamatan, melakukan penyelidikan atau percobaan, menalar, dan menjalin hubungan dengan orang lain dalam upaya memperoleh informasi atau data.

\section{Simpulan}

Berdasarkan hasil penelitian dan pembahasan dapat disimpulkan bahwa terdapat perbedaan yang signifikan hasil belajar matematika mahasiswa STMIK STIKOM Indonesia antara kelompok yang mengikuti pembelajaran dengan pendekatan saintifik berbasis asesmen projek dengan kelompok yang mengikuti pembelajaran dengan pendekatan konvensional. Hasil belajar matematika yang mengikuti pembelajaran dengan pendekatan saintifik berbasis asesmen projek memiliki rata-rata skor setelah perlakuan 76,03 lebih tinggi dari hasil belajar matematika yang mengikuti pembelajaran dengan pendekatan konvensional dengan rata-rata skor setelah perlakuan 68,8. Dengan kata lain, pendekatan saintifik berbasis asesmen projek berpengaruh terhadap hasil belajar matematika mahasiswa STMIK STIKOM Indonesia.

Saran yang dapat diajukan dalam penelitian ini antara lain: 1) bagi praktisi pendidikan agar memperhatikan kendala-kendala yang ditemui untuk dievaluasi ketika mengimplementasikan pendekatan pembelajaran yang inovatif di kelas seperti pendekatan saintifik, 2) bagi dosen agar pendekatan saintifik bisa diintegrasikan dengan bentuk asesmen yang lain sesuai dengan karakteristik materi kuliah, serta mampu mengkondisikan kelas dan waktu sehingga pendekatan saintifik bisa dilaksanakan secara optimal, 3) bagi mahasiswa agar lebih memahami, mengeksplorasi, dan mengimplementasikan konsep dalam pendekatan saintifik berbasis asesmen projek dalam pembelajaran sehingga tujuan pembelajaran bisa tercapai.

\section{Daftar Pustaka}

A. Saregar, "Pembelajaran Pengantar Fisika Kuantum dengan Memanfaatkan Media Phet Simulation dan LKM Melalui Pendekatan Saintifik: Dampak pada Minat dan Penguasaan Konsep Mahasiswa,” J. Ilm. Pendidik. Fis. Al-Biruni, vol. 5, no. 1, p. 53, 2016.

Arifin, Zaenal. 2018. Pendekatan Pembelajaran Saintifik pada Mata Pelajaran Bahasa Arab di Madrasah. Jurnal Pendidikan Bahasa Arab Vol. 10 No. 1 Hal. 1-20. Tersedia Pada: http://journal.stainkudus.ac.id/index.php/Arabia/article/view/3478/pdf.

Daryanto, Pendekatan Pembelajaran Saintifik Kurikulum 2013. Yogyakarta: Gava Media, 2014.

Siti Hamidah. 2015. Pendekatan Saintifik dalam Pembelajaran Teks Cerita Pendek pada Siswa Kelas VII Sekolah Menengah Pertama. Riksa Bahasa Volume 1, Nomor 1, Hal. 107-114). Tersedia Pada: https://ejournal.upi.edu/index.php/RBSPs/article/viewFile/8706/pdf.

Hosnan. 2014. Pendekatan Saintifik dan KontekstualDalam Pembelajaran Abad 21. Jakarta. Ghalia Indonesia.

I. M. Suarsana, N. P. Supawidhiasih, and N. N. Parwati, "The Use Of Portfolio Assessment To Overcome The Weakness Of Scientific Approach,”vol. 7, no. 1, pp. 41-50, 2018.

I. W. E. Mahendra, "Project Based Learning Bermuatan Etnomatematika Dalam Pembelajar Matematika," JPI (Jurnal Pendidik. Indones., vol. 6, no. 1, pp. 106-114, 2017.

M. and nurdyansyah Musfiqon, Pendekatan Pembelajaran Saintifik. Sidoarjo: Nizamia Learning Center, 2015.

M. Rapi, "Meningkatkan Aktivitas Dan Hasil Belajar Mata Kuliah Pengetahuan Lingkungan Hidup Melalui Pendekatan Scientific Mahasiswa," J. Biotek, vol. 4, no. 2, p. 297, 2016.

Norhayati Endah Permatasari, henny dewi Koeswati, and S. Giarti, "Muallimuna : jurnal madrasah ibtidaiyah," pp. 148-161, 2017.

Permatasari, Eka Aprilia. 2014. Implementasi Pendekatan Saintifik dalam Kurikulum 2013 pada Pembelajaran Sejarah. Indonesian Journal of History education, Vol. 3 (1) Hal. 11-16. Tersedia Pada: https://journal.unnes.ac.id/sju/index.php/ijhe/article/view/3884.

R. H. Santoso, "Implementasi Pendekatan Saintifik Mapel Matematika Kelas VII Tahun Pelajaran 2013 / 2014 pada Kurikulum 2013 DIY The Implementation of Scientific Approach in Mathematics Subject for 
Grade VII in 2013 / 2014 of Curriculum 2013 DIY,” vol. 10, pp. 80-94, 2015.

Rustam. 2017. Implementasi Pendekatan Saintifik pada Materi Menulis Teks Prosedur Siswa Kelas VII CI di SMP Negeri1 Kota Jambi. Pena Vol 7 No.2 Hal. 1-17. Tersedia Pada: https://onlinejournal.unja.ac.id/pena/article/view/4763.

S. D. I. Cinennung, D. Cinennung, K. Palakka, and K. Bone, "Jurnal Prima Edukasia , 6 ( 1 ), 2018 , 21 -31 The Effect of Using the Scientific Approach Through Concept Understanding and Critical Thinking in Science," vol. 6, no. 1, pp. 21-31, 2018.

W. Linda, "Pendekatan Saintifik \& Model Pembelajaran K-13,” Bahastra, vol. 37, no. 1, p. 89, 2017.

W. Lestari, L. D. Pratama, and J. Jailani, "Implementasi Pendekatan Saintifik Setting Kooperatif Tipe STAD Terhadap Motivasi Belajar Dan Prestasi Belajar Matematika,” AKSIOMA J. Mat. dan Pendidik. Mat., vol. 9, no. 1, pp. 29-36, 2018.

Y. Ratunguri, "Pembelajaran Berbasis Saintifik Terhadap Sikap Berpikir Ilmiah Mahasiswa Program Studi PGSD Universitas Negeri Manado,” Pedagog. J. Pendidik., vol. 4, no. 1, p. 1, 2015. 